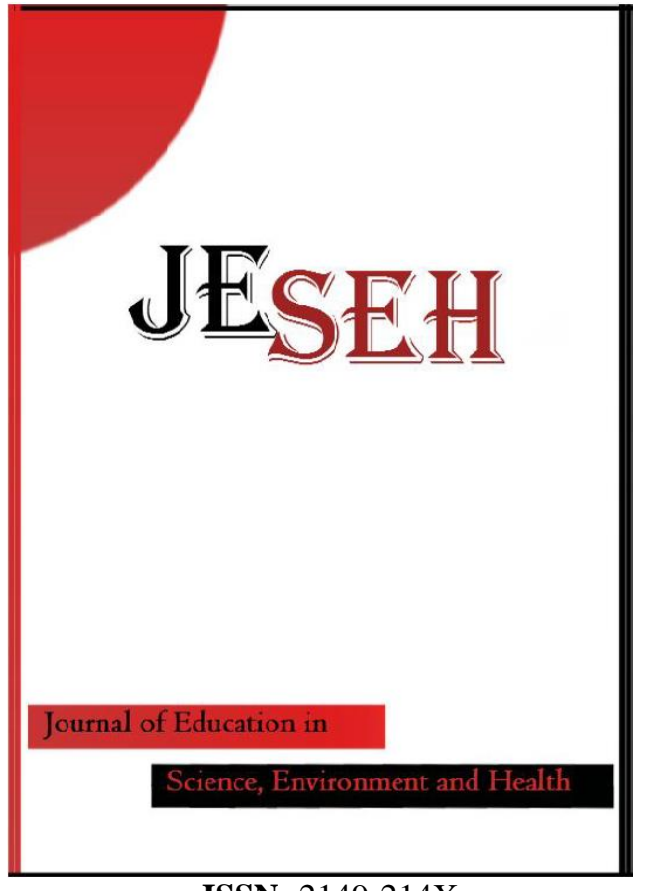

ISSN: $2149-214 \mathrm{X}$

\section{Journal of Education in Science, Environment and Health}

\section{www.jeseh.net}

Using Virtual Reality in the Classroom: Reflections of STEM Teachers on the Use of Teaching and Learning Tools

Bekir Yildirim ${ }^{1}$, Emine Sahin-Topalcengiz ${ }^{1,4}$, Gokhan Arikan $^{2}$, Serkan Timur ${ }^{3}$

${ }^{1}$ Mus Alparslan University

${ }^{2}$ Kayseri Vocational and Anatolian High School

${ }^{3}$ Canakkale Onsekiz Mart University

${ }^{4}$ İstanbul University-Cerrahpasa

To cite this article:

Yildirim, B., Sahin-Topalcengiz, E., Arikan, G., \& Timur, S. (2020). Using virtual reality in the classroom: Reflections of STEM teachers on the use of teaching and learning tools. Journal of Education in Science, Environment and Health (JESEH), 6(3), 231-245. DOI:10.21891/jeseh.711779

This article may be used for research, teaching, and private study purposes.

Any substantial or systematic reproduction, redistribution, reselling, loan, sub-licensing, systematic supply, or distribution in any form to anyone is expressly forbidden.

Authors alone are responsible for the contents of their articles. The journal owns the copyright of the articles.

The publisher shall not be liable for any loss, actions, claims, proceedings, demand, or costs or damages whatsoever or howsoever caused arising directly or indirectly in connection with or arising out of the use of the research material. 


\title{
Using Virtual Reality in the Classroom: Reflections of STEM Teachers on the Use of Teaching and Learning Tools
}

\author{
Bekir Yildirim, Emine Sahin-Topalcengiz, Gokhan Arikan, Serkan Timur
}

\begin{tabular}{|c|c|}
\hline Article Info & Abstract \\
\hline Article History & The purpose of the study was to determine teachers' opinions about virtual \\
\hline Received: & teachers after the implementation of VR practices. Teachers received three \\
\hline 21 August 2019 & $\begin{array}{l}\text { weeks of intensive training. Afterward, teachers applied VR for two months in } \\
\text { their classrooms. Later. interviews held with them. Findings indicated that }\end{array}$ \\
\hline Accepted: & different VR practices, including Google Cardboard, were used in the classroom. \\
\hline & According to the teachers, using virtual reality in the classroom captured \\
\hline Keywords & $\begin{array}{l}\text { students' interest, increased their creativity, allowed students to take virtual trips, } \\
\text { increased students' motivation, improved students' technology literacy, } \\
\text { individualized learning; made students easier to understand difficult concepts. }\end{array}$ \\
\hline Virtual reality & The potential problems of using VR were not asked the teachers; however, \\
\hline Practices & teachers mentioned that online safety and security, student access, and \\
\hline Teacher & technology gaps were the problems they faced. The findings of this study suggest \\
\hline Case study & $\begin{array}{l}\text { that the use of VR allows teachers to visualize abstract topics and enrich } \\
\text { instruction. A VR orientation module would be provided teachers with } \\
\text { opportunities to learn, practice, and apply their VR skills before being placed in } \\
\text { the classroom. }\end{array}$ \\
\hline
\end{tabular}

\section{Introduction}

The rapid changes in science and technology fields directly affected the economy and industry. As a result of this change, the individuals are expected to have different skills such as critical thinking skills, creativity, problem-solving, and virtual collaboration skills than skills business world asked workers to possess before (Davis, Fidler, \& Gorbis, 2011). The World Economic Forum (2017) also mentioned the importance of such skills (i.e., problem-solving, human management, and emotional intelligence) in today's business world. Changes from workers triggered educational reform movements around the world. Different countries have modified the science and mathematics curriculum to meet the business world expectations. Educational reforms have broadened and changed teachers' and students' roles. Schools put much pressure on teachers' shoulders, and as a result, teachers' workload has changed. Since educational reforms in science and mathematics curriculums were one domain-oriented reform, these educational change movements in education did not satisfy the business world and did not meet the needs of technology and engineering areas (Dugger, 2010). Considering science and mathematics separated from technology was one of the reasons for the failure of these educational movements (Morrison, 2006). Nuffield Foundation (1990) in England recognized this missing point and introduced the Design \& Technology (Banks \& Barlex, 2014). Afterward, countries integrated these four areas, science, technology, engineering, and mathematics into their curriculum.

A science, mathematics, technology, and engineering (STEM) education is an interdisciplinary approach that will offer students opportunities to understand the world around them (Y1ldirım, 2016). Every individual must meet the needs of 21 st-century skills and understand the basic concepts of STEM areas. Instead of separating four disciplines, STEM education integrated them into one cohesive teaching and learning paradigm $(\mathrm{Ng} \&$ Adnan, 2018). STEM had different roles while integrating different disciplines during the practice of teaching. Some researchers (such as Roehrig, Moore, Wang, \& Park, 2012) highlighted that engineering education should have a central role. On the other hand, another researcher, Corlu, Capraro, and Capraro (2014) defined STEM education was an interdisciplinary approach that mathematics and science were a vehicle to bring together concepts from more than one discipline. Additional to these perspectives, other educators put emphasized on technology. For instance, Şahin (2015) claimed that technology facilitated the discovery of new products and enhanced the implementation of STEM activities in different ways. When technology use analyzed for STEM education, two patterns emerged: (1) direct integration of technology into STEM activities design and embedding of technology into STEM activities; and (2) using technology as a facilitator of enriching STEM 
activities (Şahin, 2015). Recently, the increased availability of 3D printing, 3D modeling, robotics had opened the ways too many new applications in STEM education (Yıldırım, Yıldırım, \& Çelik, 2018; Barroso et al., 2017; Chien, 2017; Kwon, 2017). 3D printings were used as an engaging tool in students' learning. Furthermore, virtual reality (VR), augmented reality (AR), mixed reality (MR) also became widely popular in recent years and were now widely used in many different field (Aslan, 2017; Cipresso Giglioli, Raya, \& Riva, 2018).

Extended reality (XR), which blends virtual and real environments, is an umbrella term covering VR, AR, and MR. VR is an interactive computer-based environment where users interact with computer-generated environments (Schwienhorst, 2002). VR was defined as a computer-generated simulation of a 3D environment where users were immersed in learning scenarios created with computer technologies (Martín-Gutiérrez, Mora, Añorbe-Díaz, \& González-Marrero, 2017; Kayabaş1, 2005). Variety of terms are used to label the technology in the educational research literature: virtual world (VW); virtual environment (VE); multi-user virtual environment (MUVE); massively-multiplayer online (role-playing) game (MMO(RP)G); immersive virtual world (IVW); immersive world; immersive online environment; 3D virtual learning environment; open-ended virtual worlds; simulated worlds; serious virtual world; social virtual world; synthetic virtual world; and virtual learning environment (VLE) (Girvan, 2018). In this research, VR is used as a term to describe any online environment that allows users to play, learn, or interact (Girvan, 2018); VR simulates real-life experiences and constructs thoughts by using computers and various technological accessories (Duncan, Miller, \& Jiang, 2012; Hay, 1997; Yildirim, 2017). VR uses both 2D and 3D displays and provides users with realistic environments (Schwienhorst, 2002).

$\mathrm{AR}$ is a setting that combines a real setting with virtual objects. It is interactive in real-time; allows users to interact with digital images while viewing the real scene (Azuma, 1997). Though Azuma (1997) defines AR as a form of a virtual environment, there is a difference between AR and VR. VR allows users to immerse themselves in a simulated environment completely. AR supplements reality rather than completely replacing the environment. AR use digital information that would be images, audios, videos, and a touch (Kipper, 2013). AR allow users to use five senses (K1lıç, 2016). Therefore, users experience real world environment in which virtual objects and real objects are placed as seamless as possible (Kıliç, 2016). VR, on the other hand, blocks users' visual access to the real world since users' ears and eyes covered with digital screen. Another term, MR, is a setting that encompasses anything between a real scene and an immersed virtual scene (Milgram et al., 1995). Although VR, AR, and MR have been around for years, it is just entered the education arena. Until recently, a traditional computer equipped with a camera was the only technological instrument that had been used in the classroom. The explosion of mobile phones, laptops, rapid increases in computer speeds, and the increase in the availability of the internet to the public allowed to use of ER in different areas, including the classrooms. Several barriers, including high software and hardware costs, low-quality instructional design, and problems associated with the early computer systems, prohibited the use of ER in the K-12 educational settings (Olmos et al., 2018; Zantua, 2017). Recent advancements in smartphones, tablets, and laptops have weakened the obstacles and provided low-cost alternative ER technologies (Zantua, 2017). For instance, Google Cardboard viewfinder is an example of low-cost ER technologies (Truman, 2017). In 2015, Google introduced the Expeditions VR system, which is a virtual reality system for K-12 classroom use. Even though the Google Cardboard app and various VR apps provide a single user VR experience, Google Expedition provides affordable virtual field trips for the K-12 students (Lee, Sergueeva, Catangui, \& Kandaurova, 2017). To conduct a virtual field trip, the Expeditions app needs to be downloaded on a smartphone, placed in a viewfinder, and connected to the router. Students are provided with a viewfinder with an inserted smartphone opened to the Expeditions app. The teachers select the field trip location from over 500 field trips on the computer or tablet. Students then see the opening scene for the field trip. Teachers guide students through the virtual environment by asking questions. The studies' low-cost VR in educational environments is just begun to examine. The low-cost VR offers opportunities for enhancing learning across a range of areas, and this area should be investigated further (Castelvecchi, 2016).

Studies have shown that VR technology can be beneficial for students when appropriately adapted to the classroom and used (Black, 2017; Kickmeier-Rust, Hann, \& Leitner, 2019; Zhou, Ji, Xu, \& Wang, 2018). The use of VR in the classroom increases learners' engagement in an active learning environment (Allcoat \& Von Mühlenen, 2018). While students involved in the VR system, users could not interact with the real world that surrounds them. Users interact with virtual objects. VR was one of the ways to manipulate, visualize, and interact with sophisticated computer systems and data (Çavaş, 2004). Another benefit is that using VR instead of physical ones allowed students to do more experiments than physical experiments (Yıldırım, Yıldırım, \& Çelik, 2018). Thus, students collected more information in the same amount of time it would take to do physical experiments. VR was enabled students to learn more about the phenomena in the closest setting to real life by providing the learner with a three-dimensional environment (Kim, 2006). This kind of learning settings 
improves students' success. VR also allowed learners to collaborate in the learning environment (Dickey, 2005). Furthermore, VR increases students' motivation to learn (Çavaş \& Can, 2004). VR improves students' spatial abilities, whereas students' motivation for learning was improved. VR facilitate student-centered learning (Martin-Gutierrez \& Meneses, 2014; Di Serio, Ibáñez, \& Kloos, 2013). VR also improved the ability of hearingimpaired students' ability to find a solution for different problems (Passing \& Eden, 2000). Since the idea of VR introduced, there has been significant interest in using VR technology in education. VR technology has been used in K-12 and higher education in different forms such as the expeditions programs to go on virtual field trips around the world, simulations, 360-degree video and photography, head-mounted display gear, data gloves, and bodysuits to give users a fully engaged with learning experiences (Black, 2017). As the schools have greater access to technology, a growing group of teachers has started to use VR in their classroom (Castaneda et al., 2017; Aktepe, 2011; Çağıltay, Çakıroğlu, Çağıltay, \& Çakıroğlu, 2001). Even though, the benefits of VR and the difficulties of VR have been described by the research and teachers were well-supported to use VR during the instruction, the effectiveness of using VR in the classroom have not been monitored and evaluated (Çiftçi, Taşkaya, \& Alemdar, 2013; Deniz, 2005). Therefore, this study aimed to evaluate teachers' experiences of using VR in the classroom and to determine teachers' instructional technology practices in the classroom. For this research, teachers from a variety of backgrounds (one English teacher, one biology teacher, two middle school science teachers, and three geography teachers) were selected and were involved in different tasks where they can experience different applications of VR.

\section{Method}

We used a qualitative method, a case study design, to reveal teachers' opinions about VR after applying VR in the classrooms and collected qualitative data. Case studies referred to a group of methods that allows examining the in-depth study of subject or situation within a specific period (Creswell, 2003). Different data sources used in the case of studies at the same time, and this provides a holistic interpretation of the study (Merriam,1998). This approach was selected as it would allow getting an in-depth understanding of the insight teachers developed the effectiveness, usefulness, critiques, and limitations of the VR.

\section{Participants}

The stratified purposive sampling method was used to select participating teachers. The stratified purposeful sampling allows researchers to capture significant variations rather than to determine common characteristics (Patton, 1990). Seven teachers (one English teacher, one biology teacher, two middle school science teachers, and three geography teachers) from different public schools volunteered to participate in this study. Teachers were selected from different seven school sites from central Anatolia. These schools represented a range of current technology initiatives, they had well-established maintenance arrangements to quick repairs, they were well-equipped, and they were willing to share their insights after the implementation of VR. Teachers' computer skills were in general at basic to intermediate level. They did not know about VR. While selecting teachers, recommendations from technology departments in each school were taken. Technology departments evaluated teachers based on their willingness to adopt technology into the curriculum, their openness to use technology, and their experience for using technology in the classroom. Technology departments suggested potential participants from volunteer teachers.

Table 1. Demographics

\begin{tabular}{llll}
\hline \multicolumn{2}{c}{ Characteristic } & \\
\hline Organization & Gender & Subject & Experience \\
\hline Public School 1 & Male & Geography & 19 \\
Public School 2 & Female & Biology & 23 \\
Public School 3 & Female & Geography & 24 \\
Public School 4 & Female & English & 8 \\
Public School 5 & Female & Sciences & 10 \\
Public School 6 & Male & Geography & 19 \\
Public School 7 & Female & Sciences & 13 \\
\hline
\end{tabular}

Vital information (the nature and the purpose of the study) was provided to the school administrators and technology departments before the selection of teachers. After teachers were identified consent forms and informative letters sent each teacher via e-mail, and the researcher maintained all consent forms. Since the maximizing, the impact of professional development was a high priority for the researchers, teachers who would 
have a significant influence on their co-workers was another criterion. For this reason, teachers with at least three years of teaching experience were preferred over less experienced teachers. The demographics of the teachers collected through a demographic information form (Table 1).

\section{Procedures}

Three stages were involved in this study (Figure 1): (1) Pilot study: Instruction on VR took two weeks with one teacher. The first draft of the Virtual Reality Interview Form (VRIF) was given to three teachers (2) Three weeks (6 hours per week) training with teachers (3) Teachers' implementation of VR in the classroom for two months. The interviews were conducted with teachers at the end of the second month (Figure 1).

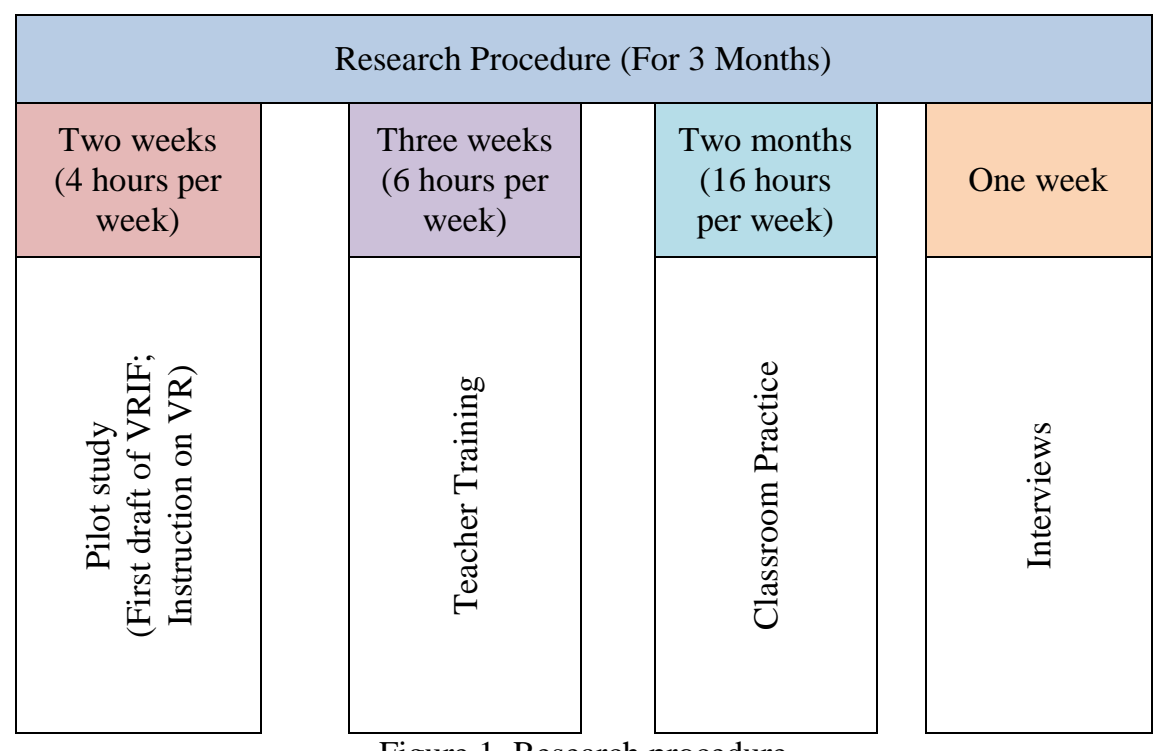

Figure 1. Research procedure

The pilot study was conducted with one elementary teacher to gather feedback from the participant experiences about using Google Cardboard and Google Expeditions, her implementation of VR, and Web 2.0 in the classroom. The elementary teacher was purposely selected for the pilot study. Since elementary teachers teach different subjects, they have content knowledge in different areas. Therefore, researchers assumed that an elementary teacher was the best option for the pilot study.

Table 2. Overview of Teaching

\begin{tabular}{|c|c|c|}
\hline \multirow{2}{*}{$\begin{array}{l}\text { Teachers } \\
\text { Geography Teachers }\end{array}$} & Scope of the course & Thematic Units in Google Expeditions \\
\hline & $\begin{array}{l}\text { Interactions in the physical } \\
\text { environment; Changing } \\
\text { populations; Climate } \\
\text { Change ( } 11^{\text {th }} \text { grade) }\end{array}$ & $\begin{array}{l}\text { Loss of Arctic Sea } \\
\text { The Sinking city if Venice } \\
\text { Deforestation in Brazil }\end{array}$ \\
\hline Biology Teacher & $\begin{array}{l}\text { Human Anatomy, Body } \\
\text { Systems }\left(11^{\text {th }} \text { grade }\right)\end{array}$ & $\begin{array}{l}\text { Human Heart, Human Respiratory System, } \\
\text { Lungs, Auditory, Digestive System, Stomach, } \\
\text { Oesophagus }\end{array}$ \\
\hline $\begin{array}{lr}\text { English } & \text { Teacher } \\
\text { (Second } & \text { Language } \\
\text { Teacher) } & \end{array}$ & $\begin{array}{l}\text { Making comparisons, } \\
\text { making simple inquiries }\left(7^{\text {th }}\right. \\
\text { grade) }\end{array}$ & $\begin{array}{l}\text { A luxury house, Human heart, Human respiratory } \\
\text { System }\end{array}$ \\
\hline Science Teachers & $\begin{array}{l}\text { Human Anatomy, Body } \\
\text { Systems }\left(6^{\text {th }} \text { and } 7^{\text {th }} \text { grade }\right)\end{array}$ & $\begin{array}{l}\text { Human Heart, Human Respiratory System, } \\
\text { Lungs, Auditory, Digestive System, Stomach, } \\
\text { Oesophagus }\end{array}$ \\
\hline
\end{tabular}

After the pilot study, the professional development curriculum revised. The latest version of the curriculum included following areas: STEM education, the role of technology in STEM areas, Technological Pedagogical Content Knowledge, Implementation of Technology in the Classroom, Web 2.0, Virtual Reality, Google Expeditions, Curriculum Development. Seven teachers received intensive training during the professional development about the subjects that were given before. Teachers developed lesson plans on different topics where they incorporated different Web 2.0 tools, Google Expeditions, and Google Cardboard. Topics were 
selected based on National Science, Biology, Geography, and Second Language Curriculum. Teachers shared student learning activity descriptions in an online classroom, Google Classroom, every week. Once the professional development completed, they implemented the lesson plans and student learning activities in the classroom during the two months. During the different implementation classes covering different topics was taught by seven instructors with extensive teaching experience in Science, Geography, English, and Biology. Topics covered in the classrooms based on subjects, grade, and thematic units in Google Expeditions were given in Table 2.

The study incorporated Virtual Reality Cardboard, similar to that shown in Figure 2, Google cardboard version 3.0 viewer in conjunction with a smartphone that is capable of running VR applications and VR $360^{\circ}$ videos in an extensive professional development for in-service teachers. VR Cardboard is an affordable technology compared to other VR devices such as head-mounted display gears and data gloves. Google Cardboard and expedition has launched in 2016 and includes a collection of linked VR content and supporting materials that can be used along with existing curriculums for different subject areas. This technology can be used for visualizing of astronomy, biology, literature, math, foreign language, geography, and physics. Nowadays, teachers and most of the students own a smartphone, tablet, and VR cardboard; and Google Cardboards can be cheaply purchased. Since the smartphones and tablets are available for students and teachers in the classroom, these devices can be easily used in conjunction with Google Cardboard and Google Expeditions if the teacher wants to use Google Cardboard while teaching, the teacher installs the Google Expedition app on a mobile device or a tablet. Expedition app is free and available on Google Play for Android devices (https://play.google.com/store/apps/details?id=com.google.vr.expeditions). Following, the teacher purchased Google Cardboard for each student from AmazonTR. The price of the cardboard was around \$4 for one student. With a single teacher tablet or a mobile phone and students' smartphones, Google Expeditions can be efficiently run during the class. Depending on students' preferences, some used tables which were available at the school and some students used their own Android phones. After installation of the app, the necessary purchasing gadgets, Google Cardboard, the teacher selects a specific VR Expedition and act a guide during that journey. Meanwhile, students open the app and act as Explorer of the teacher selected Expedition. Students view the same scene what their teachers view. Google Expeditions allow the teacher to select the content that is related to the aim of the lesson. Moreover, since each of the expeditions comes with information and questions about the $3 \mathrm{D}$ environment, this will allow students to engage with what they are seeing.

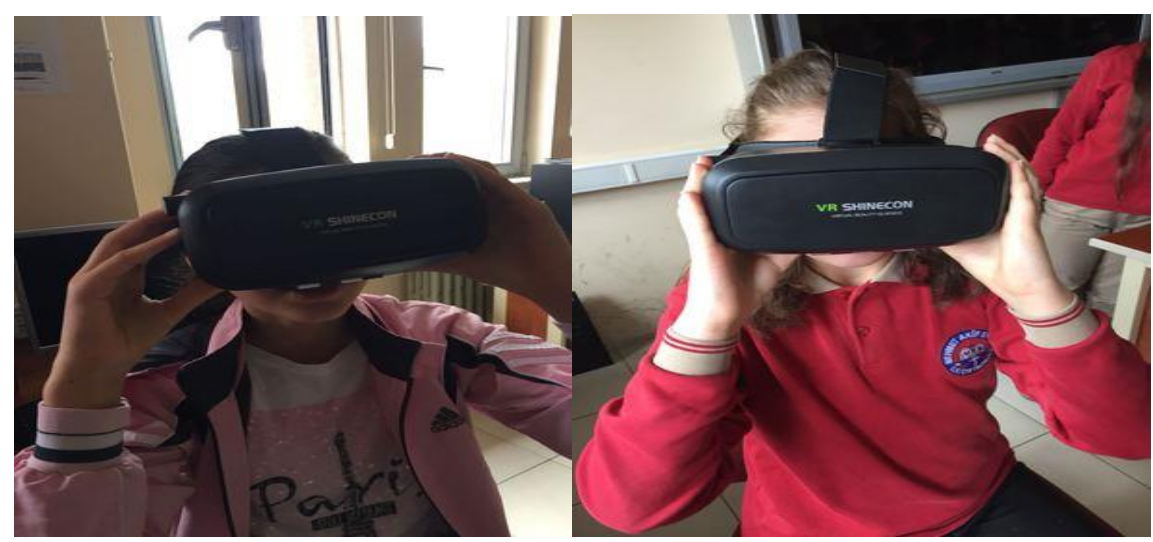

Figure 2. Virtual reality cardboard display

\section{Instruments}

Semi-structured interviews were conducted with the teachers to determine their opinions about VR. Semistructured interviews were allowed the interviewee to follow the interviewer's train of thought, allows two-way communication (Merriam, 2009)."Virtual Reality Interview Form (VRIF)" was used as a data source in this study. The first draft of the interview form consisted of 17 questions and was designed by the researchers. This form was modified according to two field experts' opinions, and this modified version was used to be interviewed with three teachers. Thirty minutes of interviews with three teachers were audio-recorded and later transcribed. After necessary small changes were made, the second version of the form was created. This second version of the form consisted of 14 questions and used for the interviews with teachers (Table 3). The interviews completed with teachers conducted after their implementation of VR in the classroom. Teachers' interviews (105 minutes) were audio-recorded. These interviews were semi-structured, and participants were asked to detail their responses given in the questionnaire. The purpose of these interviews was to get an in-depth understanding of 
teachers' use of VR. Through the interviews, the insight teachers developed regarding effectiveness, usefulness, critiques, and limitations of the use of VR to teach different subjects were examined. The study was summarized below in Table 3.

Table 3. Summary of the study

\begin{tabular}{lcl}
\hline Method & Time & Participants \\
\hline $\begin{array}{l}\text { Feedback from experts for the first draft of the } \\
\text { research questions }\end{array}$ & Three days & $\begin{array}{l}\text { Two field } \\
\text { experts }\end{array}$ \\
$\begin{array}{l}\text { Semi-structured interviews } \\
\text { Instruction on VR }\end{array}$ & 30 minutes \\
Finalization of the interview form and curriculum & Three teachers \\
Teacher training & One week & One teacher \\
VR implementation in the classroom & Two months & Seven teachers \\
Semi-structured interviews & Seven teachers \\
\hline
\end{tabular}

\section{Data Analysis}

In order to obtain the results of this study, the data collected from one instrument, the VRIF, and analyzed with content analysis methods. Content analysis methods require to transform a large amount of data into a highly organized and summary of the results (Mostyn, 1980). The data analysis was conducted by the authors and involved several steps. First, audio recordings were transcribed. Then each author independently read responses. Second, researchers discussed their interpretations of responses and came to a consensus about the codes and perceived the meaning of responses. The coder reliability for the study was calculated by using formula $[($ Consensus / Consensus + Disagreement $) * 100]$ and was calculated as $(60 / 60+15) * 100)=80 \%$ for the study (Miles \& Huberman, 1994). Since the coding results are above \%80, the coding was reliable (Miles \& Huberman, 1994).

\section{Results}

The results of the analyses are reported in the following order: teachers' opinions about instructional technology practices and teachers' opinions about the use of VR in the classroom. To gain a deeper understanding of teachers' practice, researchers first explored teachers' opinions about the use of ITP for instruction, then teachers' way of using VR was examined.

\section{Teachers' Opinions about Using the ITP for Instruction}

The result of the analyses indicated that teachers provided answers related to their ITP in the classroom. All participants confirmed their use of technology to some extent in the classroom. More than half of teachers stated that they always used technology in their classes (Figure 3). Teacher five mentioned that she used technology practices to give children a comfortable learning environment.
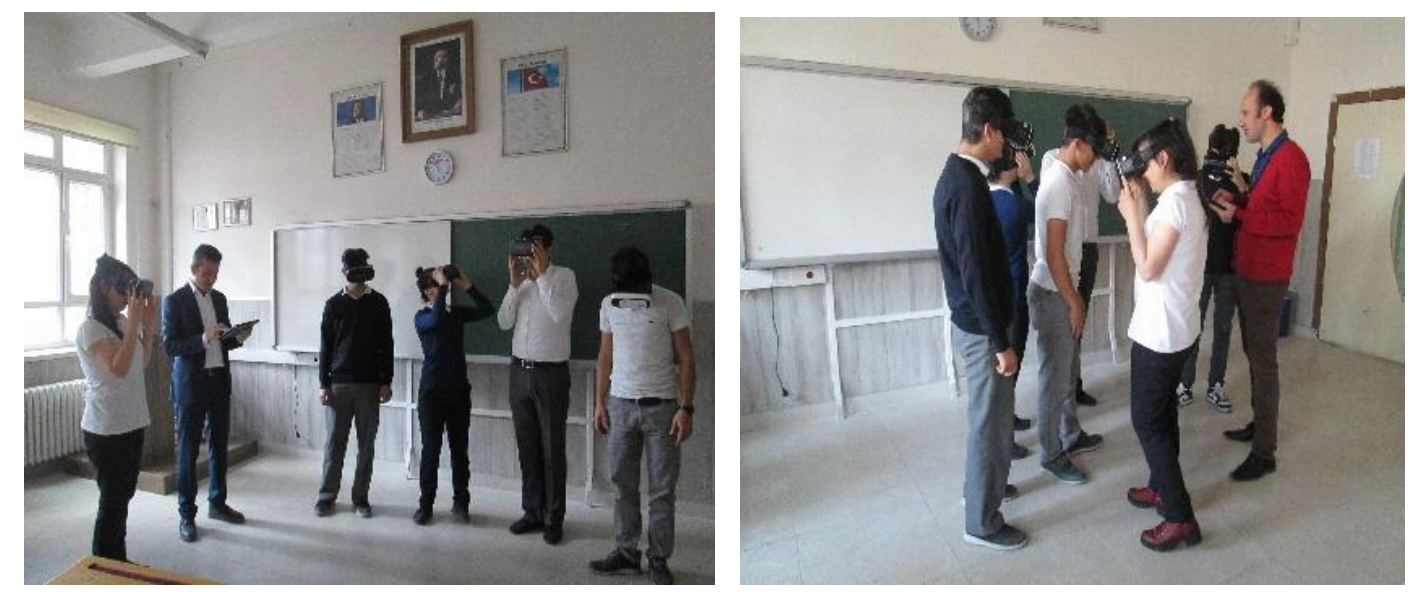

Figure 3. The sample photos from different classes 
Teacher six highlighted that her daily curricular goal determined her choice of technology use. Teacher four said she integrated technology to reinforce students' learning. The following exemplary statement provided an answer regarding technology use:

T4: I use technology practices... not always, of course. I often include during the instruction or after the instruction.

T5: I try to use technology practices at one of my lessons every week. I believe, teaching with technology practices will create a warm environment, and this will allow my students to learn.

T6: I use technological practices whenever I need them. I do not always use technology. Depending on my daily curricular goal, I decide.

Following these questions, the kinds of technology practices used by teachers in the classroom were asked. Technology practices performed by teachers included animations, slides/prezi, smartboard, increased reality and $4 \mathrm{~d}$ programs. Teachers pointed out that they mostly use animations and slides. Besides these two, smartboard applications, videos, increased reality, and the teachers also used 4D programs.

Table 4. The Benefits of Technology Use

\begin{tabular}{llc}
\hline Themes & Codes & $\mathrm{f}$ \\
\hline & Lectures supported by technology & 4 \\
& Support student centered-practice & 3 \\
& Improvement of Technology Literacy & 2 \\
The benefits of technology use & Makes difficult concepts clear for each student & 2 \\
& Establishing multiple learning setting & 1 \\
& Individualize learning & 1 \\
& Enable to see different perspectives together & 1 \\
\hline
\end{tabular}

Next, the benefits of technology use were asked to the teachers. It was concluded that using technology support students' learning, improve students' technology literacy, individualize learning, support student-centered practice, makes difficult concepts easier to understand for students, individualize learning, makes possible to establish multiple learning settings at the same time, and makes possible to see different perspectives (Table 4).

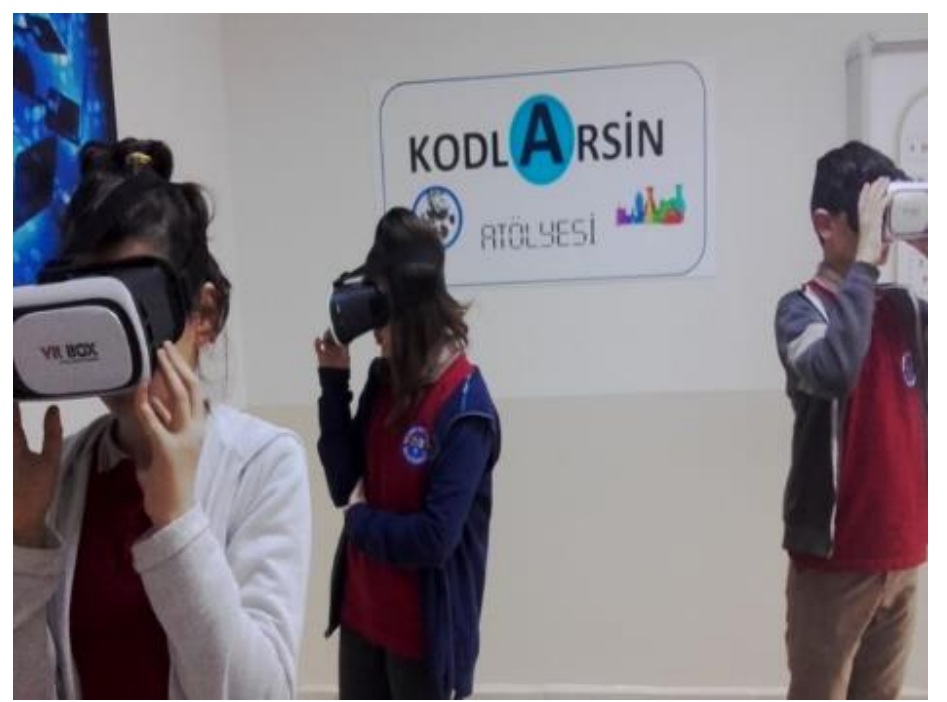

Figure 4. Sample photo of students using technology in the classroom

Several teachers with teacher-centered beliefs perceived that students' interaction with computers fosters student-centered learning. These teachers used technology to master what they already taught in the classroom. Other teachers with student-centered beliefs believed technology use in the classroom support student-centered learning and independent learning (Figure 4). With technology integration, students could learn at their own time. These teachers acknowledged that technology encourages students to explore the concepts. The exemplary answers were provided below: 
T4: Technology helps students to understand tough subjects. Thanks to simulations, virtual labs, my students get a chance to experiment in an online environment. Since doing this kind of experiment dangerous, technology also creates a safe learning environment too. Furthermore, I do not need to request some laboratory materials from my school. It is also cheap.

T5: I believed technology creates independent learners. People do not need to follow the teacher's instructions anymore. Technology allows learners to individualize instruction.

T7: Technology impacts the way my students learn. Possibly my students are more independent now because they work independently. My students take ownership of their learning. Besides technology affected the way, I evaluated my students and my preparation for the class too.

T2: When I used different technologies in the class, students' motivation increased. They do not want to finish the activity that I open on the computer.

T3: Through computers, students can reach many sources. When I use a problem-based approach, they can easily access many sources available on the internet. In the beginning, they have difficulties in differentiating reliable sources, but not they are good at it. They use these sources to solve the problem that I pose at the beginning of the class.

\section{Teachers' Opinions about the Use of VR in the Classroom}

The analyses indicated that teachers used VR for different purposes (Table 5). Teachers believed that with the help of VR, learning would be exciting and fun. Teachers recognized that the use of VR increased students' attention and motivation in the classroom (Figure 5). They also used VR to travel distant locations such as the interior of the volcano. Furthermore, teachers highlighted that VR allowed teachers to act as a facilitator in the classroom. They devoted more time to learning students' learning styles, and based on their observations, they planned adjustments in the classroom.

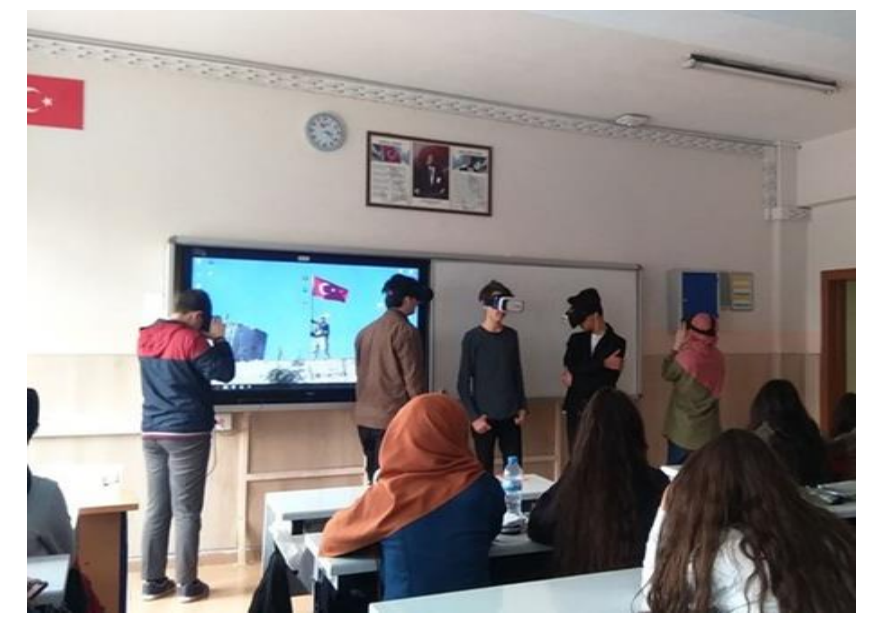

Figure 5. The Use of Virtual Reality Cardboard in the Classroom

Furthermore, VR made it possible to explore the situations that were impossible to explore in the real world with the naked eye, for example visiting the inside of matter (molecules). The exemplary answers were provided below:

T2: Some modeling and animations programs were beneficial for students to visualize some concepts. For instance, with the use of VR, students traveled inside the human body and explored the organs.

T4: I do not think VR could make teachers irrelevant in the classroom. VR allowed me to track my students' understanding of the topics that I taught and made necessary changes based on my observations and these assessments. Also, the way I assess students changed too. I believe with the appropriate use of VR; teachers act as a facilitator in the classroom. 
T5: Complex and challenging concepts such as climate change were easily explained with the use of VR. Students tried to come up with a solution for some environmental issues. This method would benefit students from a deeper level of connection with a concept.

T7: I recognized that VR learning experiences were valuable for rural students. They explored the inside of the cave. In daily life, students were not able to visit this place. Exploring caves, exploring submarines made the learning more exciting and fun. Students paid more attention to the topics and participated actively in the classroom.

Table 5. The Reasons for the Use of VR

\begin{tabular}{ll}
\hline Codes & $\mathrm{f}$ \\
\hline Teacher act as the facilitator & 4 \\
Makes abstract knowledge visible, concrete & 4 \\
Learning by doing & 2 \\
Learning in depth & 2 \\
Students' motivation increase & 1 \\
Compensation for teaching decrease & 1 \\
Individual differences were important & 1 \\
\hline
\end{tabular}

Next, the areas of VR in general use were asked to the teachers. They pointed out that VR would be used in education, health, art, construction, home, and entertainment. The exemplary answers were provided below:

T5: VR could be used in different areas: such as cinema, the entertainment industry. VR was standard in science fiction movies. It is used to turn fantastical thins into things that seem real.

T6: VR could be used in many different fields, such as education, health, and traffic. For instance, VR could be used to educate people about driving safety. Besides, doctors also use 3D models to plan their operations.

T7: VR would be used to help students with special needs. You could do exercises with autistic students using VR.

Table 6. The Benefits of VR Use

\begin{tabular}{ll}
\hline Codes & $\mathrm{f}$ \\
\hline Increase motivation & 3 \\
Learning in-depth & 3 \\
Student-centered learning & 3 \\
Teachers role change: the facilitator & 2 \\
Establish technology integration & 1 \\
Enhance teachers' ability & 1 \\
\hline
\end{tabular}

Next, the benefits of using VR were asked to the teachers. Teachers pointed out that the use of VR had some benefits. Students discovered new technologies. The VR made the teaching/learning process more exciting and fun for students. The VR could assist the teachers in improving their awareness of students' learning differences. VR was effective for experiments that difficult to carry out in the classroom. VR experiences motivated students to learn the topic. The VR increased student interest in learning activities and students fully participated in the activities. Table 6 provided a summary of teachers' opinions about the benefits of VR use. Teachers said the followings regarding the benefits of VR use they experiences:

T4: Unlike 2D visuals that I used earlier in the science class, students examined the inside of the molecules and other tiny particles in the mater. So, I had a chance to show and explain besides proton and neutron other small particles existed in the nucleus.

T5: I used to ignore tablet use in the class. Bringing a tablet with different applications into the classroom had drawn students' attention to the topic.

T6: Students found some topics boring before. With the VR applications, students paid more attention to the topic and wanted to learn the next topic. 


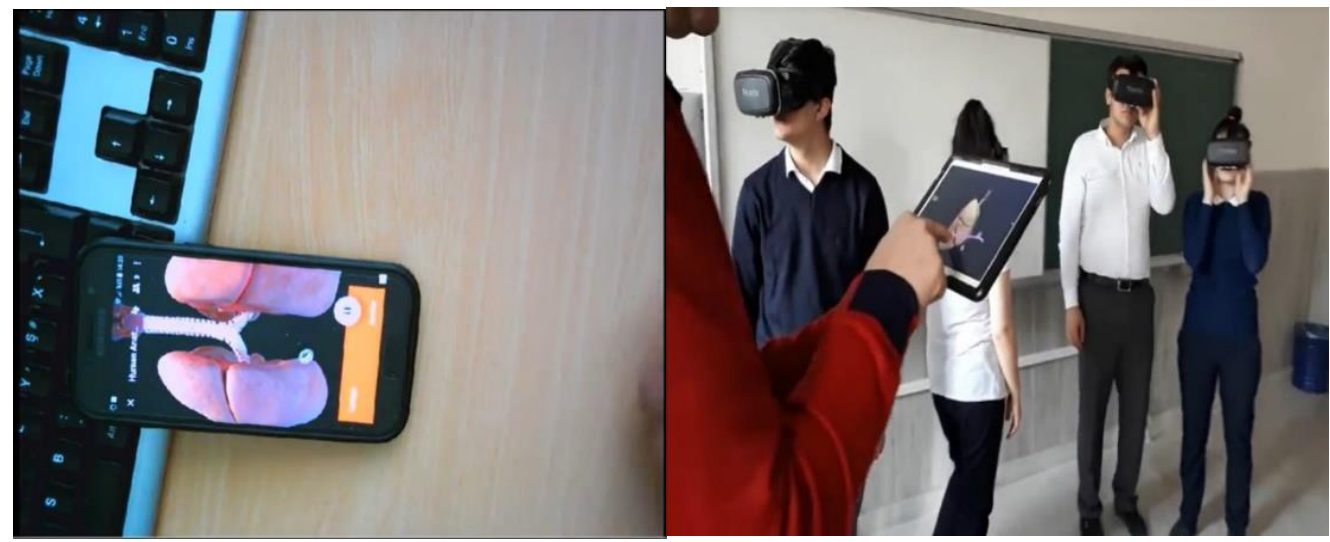

Figure 6. Use of Virtual Reality Cardboard in Education

Lastly, the question about "How does the use of VR affect your opinion about technology integration in the classroom? Why?" was asked to the teachers (Table 7). Teachers mentioned that the use of VR in the classroom enhanced their intention to use technology for education (Figure 6). During teacher training, teachers developed specific skills such as the ways of determining students' needs, identifying the most recent technology, and combined these skills into practice. The exemplary answers were provided below:

T2: The VR increased student participation and motivation for learning. VR created an experience for students to enhance their critical thinking skills cause students actively involved in problem-solving scenarios.

T3: Students were excited about the topic. I do not have any evidence that showed students' improvement in learning, but I could assure you that they were excited about learning.

Table 7. The Effect of VR Use on Technology Use in The Classroom

\begin{tabular}{lll}
\hline Theme & Codes & f \\
\hline The effect of VR uses on technology use & Positively changed & 7 \\
& Negatively changed & - \\
The positive change towards technology & Learning in-depth \\
integration the class & $\begin{array}{l}\text { Improve students' understanding } \\
\text { Increase motivation } \\
\text { Makes abstract knowledge } \\
\text { visible, concrete }\end{array}$ & 5 \\
& \\
\hline
\end{tabular}

\section{Discussion}

The present study was conducted to examine teachers' opinions about VR after the implementation of VR and ITP. The data obtained from interviews with teachers demonstrated that teachers used different instructional technology practices such as 4D programs, smartboard, simulations, animations, and videos. This finding supported by the data from captured classroom scenes too (Figure 5). This finding also supported the research which was determined teachers' instructional technology practices in the classroom (Keleş, Öksüz, \& Bahçekapıl1, 2013). Another finding from this study was that teachers used technology to prepare classroom instructional materials, to support student-centered instructions, to individualize learning, to make difficult concepts easier to understand for students. These results were consistent with the relevant literature (McKnight et al.,2016; Yüksel \& Adıüzel, 2012; Glassett \& Schrum, 2009).

Furthermore, another aim of this study was to determine teachers' opinions about VR use for instruction. Teachers pointed out that using VR for instruction offers opportunities for students. These opportunities are: (1) VR captured students' interest, increased their creativity. (2) VR could allow students to take virtual trips and to explore situations that were impossible to explore in the real world. (3) Using VR for instruction increased students' motivation and attention to the subject. (4) Using VR allowed teachers to act as a facilitator in the classroom. (5) Using VR allowed students to discovered new technologies. (6) Using VR allowed teachers to devote more time to know their students', their learning styles. (7) VR allowed teachers to carry out experiments that difficult to do in the classroom. The captured scenes from the classroom while teaching respiratory system 
support this findings as well (Figure 6).These results were consistent with relevant studies (Y1ldırım et al., 2018; Keskin, 2017; Tepe, Kaleci, \& Tüzün, 2017; Tüzün \& Özdinç, 2016; Fineschi \& Pozzebon, 2015; Jeong, Park, Kim, Oh, \& Yoo, 2011; Çoruh, 2011; Kartigo, Kavakli, \& Cheng, 2010; Sun, Lin, \& Wang, 2010; Dalgarno, Bishop, Adlong, \& Bedgood, 2009; Mishra, 2009; Aoki, Ohno, \& Yamaguchi, 2005; Manseur, 2005; Bakas \& Mikropuolus, 2003). For instance, Manseur (2005) used VR for teaching abstract topics such as molecular systems, galaxies, astronomy topics. The VR allowed students to visualize these topics and enriched instruction. Furthermore, during the interview teachers stated that VR was used in different fields in daily life such as education, health, and art.

The potential problems of using VR were not asked the teachers directly during the interviews; however, teachers mentioned that they had different barriers while implementing VR for instruction. These barriers were: safety and security, student access, and technology gap. Teachers pointed some teachers were confident in their technical abilities, but others had a lower comfort level in using and implementing the technology. They stated that teachers' age might be a barrier in their comfort level to use technology for instruction. Fernandez (2017) also highlighted that teachers were the leading facilitator for the adoption of VR for instruction. Additionally, teachers mentioned that the internet environment should be safe for students, and access to computer hardware would be ready for students. Regarding these barriers, student safety, access, and security should be a top priority before any student involvement in technology usage (Sharples, Graber, Harrison, \& Logan, 2009).

Innovation in VR provides a better learning environment for students. However, there are some risks and negative aspects of the use of this technology in schools. First, the use of this type of application may cause students to isolate themselves from their peers (Gudoniene \& Rutkauskiene, 2019; Liou et al., 2017). During the learning process, learners interact with teaching materials, imitate scientists or engineers' ways of producing knowledge/material, and collaborate with their peers, exchange ideas with one another. These types of interactions are not that common in VR environments. Even though there has been progressed made in the development of these devices, current devices only allow transferring one kind of information in one sense. There is a need to find a way to track user interaction with the environment in different senses. Current visualization tools and audio devices are expensive. For instance, one gadget from Oculus Rift and HTC Vive costs more than $\$ 300$, and both require a computer with high processing capacity. To buy a complete set of these devices to enjoy a virtual reality experience, teachers need to pay more than $\$ 3500$.

On the other hand, low-cost devices that use smartphones processing capacity exist in the market. These provided supplementary materials cost below $\$ 100$. The supplementary materials in the market allow users to interact with the material in one sense-for instance, Samsung's track-pad increases users' interaction with the environment. If the teacher wants to add headphones with high quality, this price goes up. Manufacturers do not provide supplementary materials without charging mo. Therefore, teachers need to provide all the materials which seem impossible for the whole class.

The second barrier is the schools and the teachers (Liou et al., 2017). Teachers have not been trained to use this technology in the classroom. Teachers do not know what VR is and what its possibilities and its potentials are. Teachers' knowledge of VR technology in specific educational contexts is limited, or they do not know. Teachers' limited or no knowledge is, without a doubt, one of the main barriers.

The next barrier is content of VR technologies. The current VR content is not adopted based on topics in the curriculums. The current VR contents only offer students exciting experiences. Using them as teaching material or adapting them as classroom material is not easy or possible always. These materials must feed the curriculum and vice versa.

\section{Conclusions}

The use of VR in education has grown dramatically in recent years as a result of drastic improvements in technology and low manufacturing cost. Drop-in prices have made VR more accessible to the schools. The use of VR in the classroom allowed students to interact with unobservable phenomena, to take virtual trips, increased students' motivation, engagement, and creativity. Further, the use of these tools allowed teachers to act as a facilitator in the classroom. On the other hand, the use of VR brought some barriers as well such as safety and security, student access, and technology gap. Teachers' confidence and comfort level might be a factor that affects teachers' implementation of VR for instruction. An essential conclusion regarding teachers' comfort level was that teachers unconsciously might be rejecting the use of new technologies in the instruction. The possibilities for educators to explore, learn, and experience a VR should be offered for teachers. An orientation 
module would be provided teachers with opportunities to learn, practice, and apply their VR skills before being placed in the classroom. Fernandez (2017) also supported the idea of developing modules for teachers and added two fundamental points of any VR training of teachers must have (1) The detailed information about VR (2) Possibilities and potentials of VR. Teachers also highlighted that whoever participates in VR, they must have the necessary computer skills. Furthermore, teachers should keep students safe in online environments. Further, support and collaboration between the instructional technology department, other departments, and law enforcement should determine students' safety and security in VR environments.

\section{Limitations}

The limitation of this study was based on the generalizability characteristics of the study. As previously mentioned, the research participants were selected from volunteers. Teachers' VR experience did not consider as a criterion for selecting a research participant. Therefore, future research should select teachers who met the criteria of having VR experience. VR had not been used for instructional purposes or enrichment activities in different subjects before. Since students had never been experienced VR, future research focuses on longitudinal studies across a school year to mitigate the effect of using the new approach. Due to time constraints, the shortage of the funds, and diverse cities teachers were in, only interviews conducted with teachers after the study. Therefore, additional qualitative data sources such as classroom observations, interviews with students, and the quantitative data sources such as surveys should be used as data sources in future studies. A case study for each teacher may also provide additional insight into teachers' and students' experiences with VR, as well as better insight into how VR influences students' and teachers' motivation, and students' learning.

\section{Acknowledgments or Notes}

The authors would like to acknowledge and thank the teachers and students for their participation in the research.

\section{References}

Aktepe, V. (2011). The classroom teachers' views on computer use in their courses. Ahi Evran University Journal of Faculty of Education, 12(3), 75-92.

Allcoat, D., \& A Von Mühlenen, A. (2018). Learning in virtual reality: Effects on performance, emotion and engagement. Research in Learning Technology, (26). - http://dx.doi.org/10.25304/rlt.v26.2140

Aslan, R. (2017). Uluslararası Rekabette Yeni İmkanlar Sanal Gerçeklik, Artırılmış Gerçeklik ve Hologram. Göller Bölgesi Aylık Hakemli Ekonomi ve Kültür Dergisi, 5(49), 21-28.

Aoki, H., Ohno, R., \& Yamaguchi, T. (2005). The effect of the configuration and the interior design of a virtual weightless space station on human spatial orientation. Acta Astronautica, 56, 1005-1016. https://doi.org/10.1016/j.actaastro.2005.01.028

Arıc1, V. A. (2013). A study on 3D-virtual reality in science education programs: 'Solar system and beyond: Space puzzle' unit sample. (Unpublished master thesis). Menderes University: Aydın.

Azuma, R. T. (1997). A survey of augmented reality. Presence: Teleoperators and virtual environments, 6(4), 355-385.

Bakas, C., \& Mikropoulos, T. A. (2003). Design of virtual environments for the comprehension of planetary phenomena based on students' ideas. International Journal of Science Education, 25, 949-467. https://doi.org/10.1080/09500690305027

Banks, F., \& Barlex, D. (2014). Teaching STEM in the secondary school: How teachers and schools can meet the challenge. London: Routledge.

Barroso, L.R., Bicer, A., Capraro, M.M., Capraro, R.M., Foran, A.L., Grant, M.R., \& Rice, D. (2017). Run! Spot. Run!: vocabulary development and the evolution of STEM disciplinary language for secondary teachers. ZDM, 49(2), 187-201. https://doi.org/10.1007/s11858-016-0826-4.

Black, E. R. (2017). Learning then and there: an exploration of virtual reality in $k-12$ history education. (Unpublished doctoral thesis), The University of Texas: Texas.

Blanchard, M. R., LePrevost, C. E., Tolin, A. D., \& Gutierrez, K. S. (2016). Investigating technology-enhanced teacher professional development in rural, high-poverty middle schools. Educational Researcher, 45(3), 207-220. https://doi.org/10.3102/0013189X16644602. 
Castaneda, L., Cechony, A., \& Bautista A. (2017) Applied VR in the schools, 2016-2017 aggregated report. Retrieved from 01/1/19. http://www.foundry10.org/research/all-school-aggregated-findings-virtualreality-2016-2017.

Castelvecchi, D. (2016). Low-cost headsets boost virtual reality's lab appeal. Nature 533, 153-154. doi: $10.1038 / 533153 \mathrm{a}$

Çavaş, B., Çavaş, P. H., \& Taşkın Can, B. (2004). Eğitimde sanal gerçeklik [Virtual reality in education]. The Turkish Online Journal of Educational Technology, 3(4), 110-116.

Çağıltay, K., Çakıroğlu, J., Çağıltay, N., Çakıroğlu, E. (2001). Teachers' perspectives about the use of computers in education. Hacettepe Üniversitesi Ĕgitim Bilimleri Dergisi, 21(1), 19-28.

Chien, Y.H. (2017). Developing a pre-engineering curriculum for 3d printing skills for high school technology education. Eurasia Journal of Mathematics, Science and Technology Education, 13(7), 2941-2958.

Çiftçi, S., Taşkaya, S. M., \& Alemdar, M. (2013). The Opinions of classroom teachers about fatih project. Illkögretim Online, 12 (1), 227-240.

Cipresso P., Giglioli I.A.C., Raya M.A., \& Riva, G. (2018) The past, present, and future of virtual and augmented reality research: a network and cluster analysis of the literature. front. Psychol. 9(2086). doi: $10.3389 /$ fpsyg.2018.02086

Corlu, M. S., Capraro, R. M., \& Capraro, M. M. (2014). Introducing STEM education: implications for educating our teachers for the age of innovation. Education and Science, 39 (171), 74-85. http://hdl.handle.net/11693/13203

Çoruh, L. (2011). Assessment of the effectiveness of virtual reality applications in art history course as a learning model (An example of Erciyes University Architecture \& Fine Art Faculties). (Unpublished doctoral thesis). Gazi University: Ankara.

Creswell, J.W. (2003). Research design: Qualitative, quantitative, and mixed methods approach. California: Sage Publications Inc.

Dalgarno, B., Bishop, A. G., Adlong, W., \& Bedgood, D. R. (2009). Effectiveness of a virtual laboratory as a preparatory resource for distance education chemistry students. Computers \& Education, 53(3), 853865. https://doi.org/10.1016/j.compedu.2009.05.005

Dalgarno, B., \& Lee MJ. (2010). What are the learning affordances of 3-D virtual environments?. British Journal of Educational Technology, 41(1), 10-32. https://doi.org/10.1111/j.1467-8535.2009.01038.x

Davies, A., Fidler, D., \& Gorbis, M. (2011). Future work skills 2020. Phoenix: Institute for the future for University of Phoenix Research Institute.

Deniz, L. (2005). Elementary and middle school teachers attitudes towards computer use. Turkish Journal of Educational Technology, 4(4), 191-203.

Dickey, D. M. (2005). Three-dimensional virtual worlds and distance learning: Two case studies of active worlds as a medium for distance education. British Journal of Educational Technology, 36(3), 439-451. https://doi.org/10.1111/j.1467-8535.2005.00477.x

Di Serio, A., Ibáñez, M. B., \& Kloos, C. D. (2013). Impact of an augmented reality system on students' motivation for a visual art course. Computers \& Education, 68, 586-596. https://doi.org/10.1016/j.compedu.2012.03.002

Dugger, W. E. (2010). Evolution of STEM in the United States. Retrieved from http://citeseerx.ist.psu.edu/viewdoc/download;jsessionid=6097F21C33E48488B6FEA4F106585D23?d $\mathrm{oi}=10.1 .1 .476 .5804 \& \mathrm{rep}=\mathrm{rep} 1 \&$ type $=$ pdf

Duncan, I., Miller, A., \& Jiang, S. (2012). A taxonomy of virtual worlds usage in education. British Journal of Educational Technology, 43(6), 949-964. https://doi.org/10.1111/j.1467-8535.2011.01263.x

Fernandez, M. (2017). Augmented virtual reality: how to improve education systems. Higher Learning Research Communications, 7(1), 1-15. Retrieved from http://files.eric.ed.gov/fulltext/EJ1150087.pdf

Fineschi, A., \& Pozzebon, A. (2015). A 3D virtual tour of the santa maria della scala museum complex in Siena, Italy, based on the use of oculus rift HMD. In 3D Imaging (IC3D), 2015 International Conference on $3 D$ Imaging (IC3D) IEEE, pp. 1-5.

Girvan, C. (2018). What is a virtual world? Definition and classification. Educational Technology Research and Development, 66(5), 1087-1100. https://doi.org/10.1007/s11423-018-9577-y

Glassett, K., \& Schrum, L. (2009). Teacher beliefs and student achievement in technology-rich classroom environments. International Journal of Technology in Teaching and Learning, 5(2), 138-153.

Gudoniene, D., \& Rutkauskiene, D. (2019). Virtual and Augmented Reality in Education. Baltic Journal of Modern Computing, 7(2), 293-300.

Hay, K. E. (1997). Educational application of virtual reality: A rational and case studies of 3D visualization and world building. Paper presented at the Indiana University Virtual Reality Conference, Bloomington, IN.

Jeong, J. S., Park, C., Kim, M., Oh, W. K., \& Yoo, K. H. (2011). Development of a 3D virtual laboratory with motion sensor for physics education. (In T. H. Kim, H. Adeli, R. J. Robles, \& M. Balitanas (Eds.)), 
Ubiquitous Computing and Multimedia Applications, (Vol. 150, pp. 253-262). Berlin: Springer-Verlag Berlin.

Kaleci, D., Tepe, T., \& Tüzün, H. (2017). Üç boyutlu sanal gerçeklik ortamlarındaki deneyimlere ilişkin kullanıc1 görüşleri (Users opinions of experiences in three-dimensional virtual reality environments). Türkiye Sosyal Araştırmalar Dergisi, 3, 669-689.

Kartigo, I., Kavakli, M., \& Cheng, K. (2010). Learning science in a virtual reality application: The impacts of animated-virtual actors' visual complexity. Computers \& Education, 55, 881-891. https://doi.org/10.1016/j.compedu.2010.03.019

Kayabaşı, Y. (2005). Sanal gerçeklik ve eğitim amaçlı kullanılması (Virtual reality and its use in education). The Turkish Online Journal of Educational Technology, 4(3), 151-158.

Kılıç, T. (2016). Sanal gerçeklik teknolojisinin mekânsal deneyim odaklı kullanımı üzerine bir inceleme [A Study on the Effects of using Virtual reality on spatial ability]. 5th International Interior Design Syposium. Istanbul: Turkey.

Kim, P. (2006). Effects of the 3d virtual reality of plate tectonics on fifth-grade students' achievement and attitude toward science. Interactive Learning Environments, 14(1), 25-34.

Keleş, E., Öksüz, B. D., \& Bahçekapıl1, T. (2013). Teachers' opinions regarding the use of technology in education: fatih project example. Gaziantep University Journal of Sciences, 12 (2), 353-366.

Keskin, İ. (2017). Matematik öğretmeni adaylarının eğitimde sanal gerçeklik kullanımına ilişkin görüşlerinin değerlendirilmesi (Pre-service mathematics teachers' opinions about the use of virtual reality in education). Avrasya Sosyal ve Ekonomi Araştırmaları Dergisi (ASEAD), 4(11), 294-302.

Kickmeier-Rust M.D., Hann P., \& Leitner M. (2019) Increasing Learning Motivation: An Empirical Study of VR Effects on the Vocational Training of Bank Clerks. In: van der Spek E., Göbel S., Do EL., Clua E., Baalsrud Hauge J. (eds) Entertainment Computing and Serious Games. ICEC-JCSG 2019. Lecture Notes in Computer Science, vol 11863. Springer.

Kipper, G. (2013). What Is Augmented Reality? In: G. Kipper and J.Rampolla (eds) Augmented Reality. 2013, (pp.1-27). Syngress, Elsevier.https://doi.org/10.1016/B978-1-59-749733-6.00001-2.

Kwon, H. (2017). Effects of 3d printing and design software on students' overall performance. Journal of STEM Education, 18(4), 37-42.

Lee, S.H., Sergueeva, K., Catangui, M., \& Kandaurova, M. (2017) Assessing google cardboard virtual reality as a content delivery system in business classrooms. Journal of Education for Business, 92(4), 153-160, DOI: $10.1080 / 08832323.2017 .1308308$

Liou, H. H., Yang, S. J., Chen, S. Y., \& Tarng, W. (2017). The influences of the 2D image-based augmented reality and virtual reality on student learning. Journal of Educational Technology \& Society, 20(3), 110-121.

Manseur, R. (2005- October). Virtual reality in science and engineering education. 35th ASEE/IEEE Frontiers in Education Conference, Indianapolis, IN.

Martín-Gutiérrez, J., Mora, C. E., Añorbe-Díaz, B., González-Marrero, A. (2017). Virtual technologies trends in education. Eurasia Journal of Mathematics, Science and Technology Education, 13(2), 469-486. https://doi.org/10.12973/eurasia.2017.00626a

McKnight, K., O'Malley, K., Ruzic, R., Horsley, M. K., Franey, J. J., \& Bassett, K. (2016). Teaching in a digital age: How educators use technology to improve student learning. Journal of Research on Technology in Education, 48(3), 194-211. https://doi.org/10.1080/15391523.2016.1175856

Merriam, S. B. (1998). Qualitative research and case study applications in education. Revised and expanded from" case study research in education. San Francisco: Jossey-Bass Publishers.

Miles, M, B., \& Huberman, A. M. (1994). Qualitative data analysis: An Expanded Sourcebook. (2nd ed). Thousand Oaks, CA: Sage.

Milgram, P., \& Kishino, F. (1994). A taxonomy of mixed reality visual displays. IEICE TRANSACTIONS on Information and Systems, 77(12), 1321-1329.

Mishra, S. (2009). Virtual Worlds. (In S. Mishra (Ed.)), E-Learning (ss. 110-113). New Delhi: Indira Gandhi National Open University.

Morrison, J. (2006). TIES STEM education monograph series, attributes of STEM education - Baltimore, MD: TIES.

Mostyn, B. (1985). The Content Analysis of qualitative research data: a dynamic approach. (In Brenner, M., Brown, J., and Canter, D., Eds.), The Research interview: uses and approaches. London: Academic Press.

Ng, C.H., \& Adnan, M. (2018). Integrating STEM education through Project-Based Inquiry Learning (PIL) in topic space among year one pupils. Materials Science and Engineering 296(2018), 1-6. doi:10.1088/1757-899X/296/1/012020

Olmos, E., Cavalcanti, J. F., Soler, J., Contero, M., \&Alcaniz, M. (2018). Mobile virtual reality: A promising technology to change the way we learn and teach. In S. Yu, M. Ally, \& A. Tsinakos (Eds.), Mobile and 
ubiquitous learning. Perspectives on rethinking and reforming education (pp. 95-106). Singapore: Springer Nature Singapore.

Tepe, T., Kaleci, D., \& Tüzün, H. (2016). Eğitim teknolojilerinde yeni eğilimler: Sanal gerçeklik uygulamaları (New Trends in Instructional Technology: Virtual Reality). 10th International Computer Education and Instructional Technologies Symposium Proceedings, Rize Turkey (pp. 547-555).

Truman, B. (2017). New Constructions for Understanding using Virtual Learning- Towards Transdisciplinarity. In A. Stricker, C. Calongne, B. Truman, \& F. Arenas (Eds.), Integrating an Awareness of Selfhood and Society into Virtual Learning (pp. 298-316). Hershey, PA: IGI Global. doi:10.4018/978-1-5225-21822.ch019.

Tüzün, H., \& Özdinç, F. (2016). The effects of 3D multi-user virtual environments on freshmen university students' conceptual and spatial learning and presence in departmental orientation. Computers \& Education, 94, 228-240.

Passig, D. \& Eden, S. (2000). Improving flexible thinking in deaf and hard of hearing children with virtual reality technology. American Annals of the Deaf, 145(3), 286-291.

Patton, M. Q. (1990). Qualitative evaluation and research methods. Thousand Oaks, CA, US: SAGE Publications.

Roehrig, G. H., Moore, T. J., Wang, H. H., \& Park, M. S. (2012). Is adding the E enough?: Investigating the impact of K-12 engineering standards on the implementation of STEM Integration. School of Engineering Education Faculty Publications. Paper 6. https://doi.org/10.1111/j.19498594.2011.00112.x

Şahin, A. (Ed.). (2015). A Practice-based model of STEM teaching: STEM students on the stage (SOS). Rotterdam: Sense Publishers.

Sharples, M., Graber, R., Harrison, C., \& Logan, K. (2009). E-safety and Web 2.0 for children aged 11-16. Journal of Computer Assisted Learning, 25(1), 70-84. https://doi.org/10.1111/j.13652729.2008.00304.x

Sun, K.T., Lin, C.L., \& Wang, S.M. (2010). A 3-D virtual reality model of the sun and the moon for e-learning at elementary schools. International Journal of Science and Mathematics Education, 8(4), 689-710. https://link.springer.com/article/10.1007\%2Fs10763-009-9181-z

World Economic Forum (2017). What are the 21st-century skills every student needs?. Retrieved from https://www.weforum.org/agenda/2016/03/21st-century-skills-future-jobs-students/

Y1ldırım, B., (2016). An examination of the effects of science technology engineering mathematics (stem) application and mastery learning integrated into the 7th-grade science course. (Unpublished doctoral thesis). Gazi University: Ankara.

Yildirim, G. (2017). The users' views on different types of instructional materials provided in virtual reality technologies. European Journal of Education Studies, 3(11), 150-172. doi: 10.5281/zenodo.1045349

Yıldırım, G., Yıldırım, S., \& Çelik, E. (2018). A New insight - 3d printers and their instructional use: a content analysis. Bayburt Eğitim Fakültesi Dergisi, 13(25), 163-184. Retrieved from http://dergipark.gov.tr/download/article-file/498694

Yildirim, G., Alban, M., \& Yildirim, S. (2018). Analysis of the use of virtual reality technologies in history education: a case study. Asian Journal of Education and Training, 4(2), 62-69.

Yüksel, İ., \& Adigüzel, A. (2012). Evaluation of teachers' instructional technologies integration skills: a qualitative need analysis for new pedagogical approaches. Necatibey Faculty of Education Electronic Journal of Science and Mathematics Education, 6(1), 265-286.

Zantua, L. (2017). Utilization of virtual reality content in grade 6 social studies using affordable virtual reality technology. Asia Pacific Journal of Multidisciplinary Research, 5(2), 1-10.

Zhou, Y., Ji, S., Xu, T., \& Wang, Z. (2018). Promoting knowledge construction: a model for using virtual reality interaction to enhance learning. Procedia Computer Science, 130(2018), 239-246. 10.1016/j.procs.2018.04.035

Author Information

Bekir Yıldırım
Muş Alparslan University
Muş, Turkey
Contact e-mail: bekir58bekir@gmail.com
ORCID iD: 0000-0002-5374-4025

Gökhan Arıkan

Kayseri Vocational and Anatolian High School Kayseri, Turkey ORCID iD: 0000-0002-6146-2247

\author{
Emine Şahin-Topalcengiz \\ Muş Alparslan University Muş, Turkey \\ İstanbul University-Cerrahpaşa, İstanbul,Turkey \\ ORCID iD: 0000-0002-2916-6886
}

\author{
Serkan Timur \\ Çanakkale Onsekiz Mart University \\ Çanakkale, Turkey \\ ORCID iD: 0000-0002-4949-2275
}

